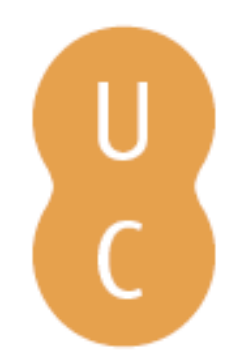

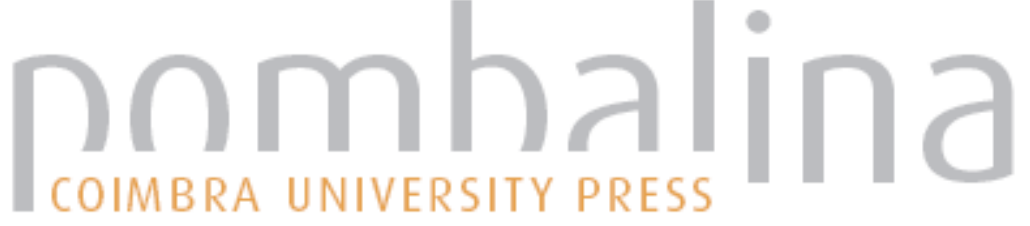

\section{Comunicação e justiça: o texto legislativo}

Autor(es): $\quad$ Rodrigues, Maria da Conceição Carapinha

Publicado por: Imprensa da Universidade de Coimbra

URL

persistente:

URI:http://hdl.handle.net/10316.2/38565

DOI:

DOI:http://dx.doi.org/10.14195/978-989-26-0770-2_4

Accessed : $\quad$ 26-Apr-2023 11:33:01

A navegação consulta e descarregamento dos títulos inseridos nas Bibliotecas Digitais UC Digitalis, UC Pombalina e UC Impactum, pressupõem a aceitação plena e sem reservas dos Termos e Condições de Uso destas Bibliotecas Digitais, disponíveis em https://digitalis.uc.pt/pt-pt/termos.

Conforme exposto nos referidos Termos e Condições de Uso, o descarregamento de títulos de acesso restrito requer uma licença válida de autorização devendo o utilizador aceder ao(s) documento(s) a partir de um endereço de IP da instituição detentora da supramencionada licença.

Ao utilizador é apenas permitido o descarregamento para uso pessoal, pelo que o emprego do(s) título(s) descarregado(s) para outro fim, designadamente comercial, carece de autorização do respetivo autor ou editor da obra.

Na medida em que todas as obras da UC Digitalis se encontram protegidas pelo Código do Direito de Autor e Direitos Conexos e demais legislação aplicável, toda a cópia, parcial ou total, deste documento, nos casos em que é legalmente admitida, deverá conter ou fazer-se acompanhar por este aviso.

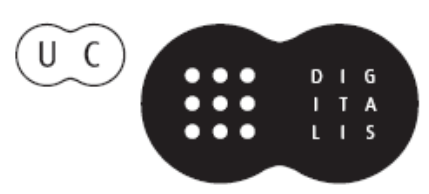



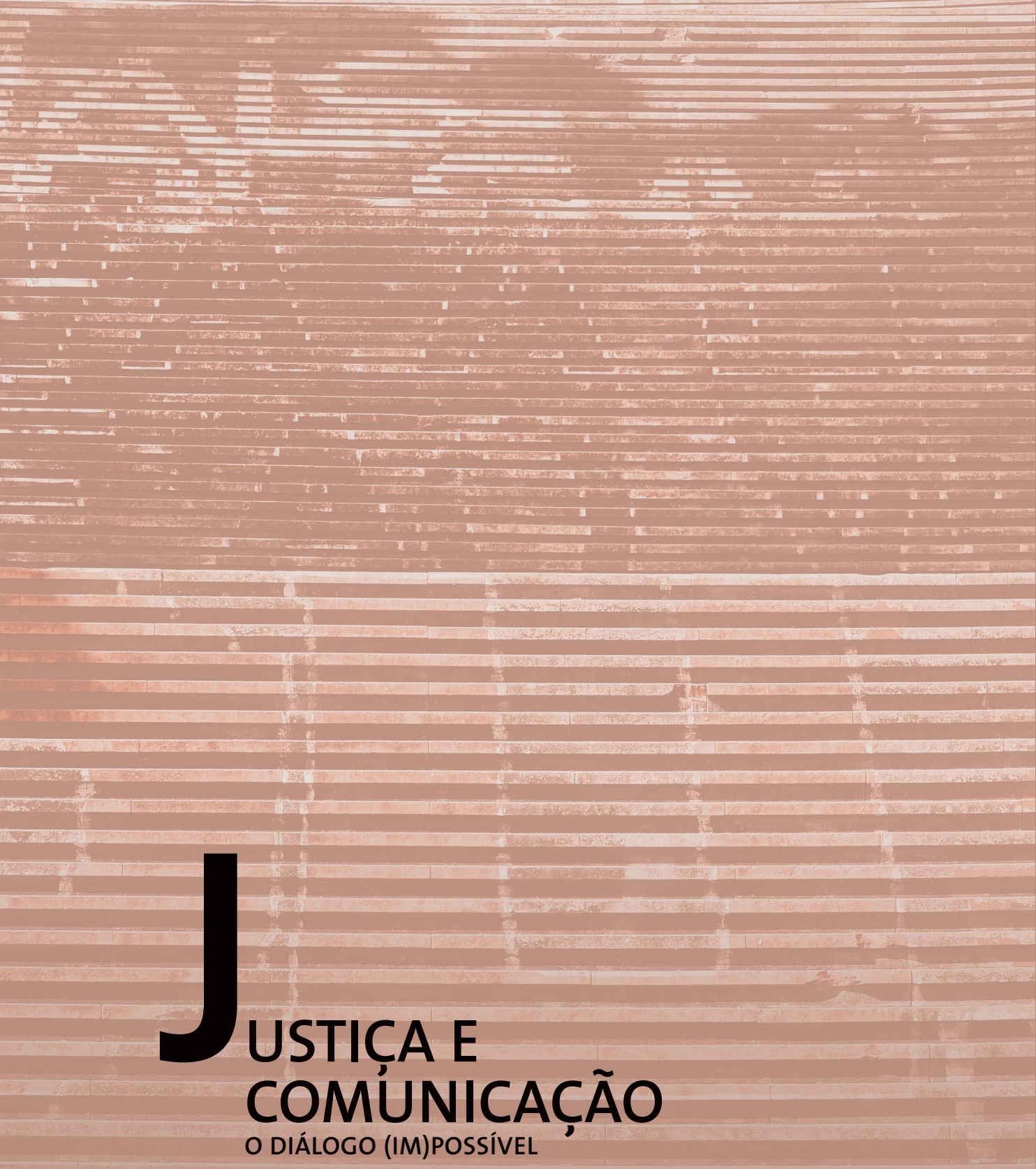

Rita Basilio Simões

Carlos Camponez

Ana Teresa Peixinho

ORGANIZAÇÃO 


\section{Maria da Conceição Carapinha Rodrigues}

(Faculdade de Letras da Universidade de Coimbra)

\section{COMUNICAÇÃO E JUSTIÇA - O TEXTO LEGISLATIVO}

\section{Introdução}

Este artigo surge na sequência do Colóquio Justiça e Comunicação, realizado na Universidade de Coimbra, em 3 de junho de 2011, e organizado pela Secção de Comunicação do Departamento de Filosofia, Comunicação e Informação (da Faculdade de Letras da Universidade de Coimbra) e pelo Conselho Superior da Magistratura.

Se o público-alvo pretendido pelo Encontro visava, sobretudo, os profissionais do Direito e da Comunicação Social, o tópico que esteve na sua génese, aparentemente mais direcionado para a análise das relações, por vezes tensas e quase sempre de mútua incompreensão, entre a Justiça e os media, estimulou a abertura do Colóquio a outras áreas interessadas na articulação entre a comunicação e o universo do Direito.

É precisamente neste âmbito interdisciplinar que se inscreve o presente texto. Não integrando o universo do Direito nem a área do Jornalismo, a Linguística (domínio de que este texto é tributário) permite olhar esse tópico a partir de um outro ponto de vista. Nesta triangulação de perspetivas o que é que sobressai como denominador comum? A comunicação e, mais concretamente, a linguagem, instrumento privilegiado de comunicação entre os seres humanos. ${ }^{77}$

77 Não esgotando, de facto, as possibilidades de estabelecer comunicação com outrem (veja-se o valor das expressões faciais, do olhar, dos gestos e da proxémica, na comunicação oral, e o valor da pontuação e dos recursos gráficos, na escrita, só para citar alguns dos meios de comunicação não verbal), a linguagem assume, todavia, uma relevância indiscutível. 


\section{Linguística - breve historial}

É precisamente a linguagem verbal humana o objeto de estudo dos linguistas. Durante grande parte do século $\mathrm{xx}$, a Linguística, nas suas duas correntes de investigação maiores - estruturalismo e gerativismo interessou-se apenas pela análise imanente da linguagem, descrevendo-a como um objeto de estudo idealizado, perspetivando-a como um sistema de signos (estruturalismo) ou como um conjunto de regras (gerativismo), sem qualquer ligação com os contextos de uso e com os falantes.

Em ambas as linhas de investigação, o significado apresentava-se como "configuração estável de índole marcadamente informativa-representativa-descritiva" (Fonseca, 1994: 95), implicando, em certa medida, a estabilidade dos objetos do mundo e dos estados de coisas a que, via linguagem, acedemos. ${ }^{78}$ A linguagem era, pois, visionada como um sistema de signos que, quando usados em contextos particulares, produzia significados de natureza eminentemente informativa e que, de forma especular, retratava e reproduzia um mundo pré-existente.

A gradual abertura da disciplina a outras áreas conexas, concomitante com uma perspetiva mais ligada aos usos linguísticos socialmente situados, inflexão que muito deve ao trabalho pioneiro de Wittgenstein e de Bakhtin, originou uma viragem da Linguística para áreas como o sujeito falante e as suas circunstâncias enunciativas, a intersubjetividade e a interação ou, por outras palavras, o discurso.

Tendo em conta este 'novo'79 paradigma, percebe-se o cada vez maior interesse da Linguística contemporânea pelos discursos do dia-a-dia, pelas interações verbais devidamente contextualizadas e pela forma como a linguagem desempenha um papel fulcral na estruturação e na configuração dessas interações que são também, e sempre, práticas sociais de construção de sentidos/significados. Mais, ao dar relevância aos discursos socialmente

78 Estamos aqui, obviamente, a lidar com dois conceitos distintos: o de significado e o de referência. O primeiro designa, em algumas teorias, uma representação mental, um conceito, enquanto o segundo indica a relação estabelecida entre uma expressão linguística e uma entidade do mundo (um ser, um objeto, um evento...).

${ }^{79}$ Em rigor, não se trata propriamente de uma rutura, mas antes de um continuum. 
situados e à dinâmica das interações, o plano significativo das línguas visto como sistema orientado para a descrição-representação de um mundo estático e isolado da própria dinâmica da interação - teve de abrir-se, portanto, a considerações de natureza contextual que alargam, substancialmente, a conceção tradicional, e estreita, de significado. A Linguística passa a questionar a visão da língua que privilegia a sua funcionalidade de mera transmissora de informações de natureza representativa: mais do que a ferramenta capaz de traduzir fiel e objetivamente uma realidade que lhe é exterior e pré-existente, a língua começa a ser perspetivada como o utensílio modelador dessa realidade. E essa modelação constrói-se nas e pelas práticas linguísticas em que os falantes, seres sócio-históricos, se embrenham, em contextos interacionais diversos. Por outras palavras, são os falantes em interação que negoceiam significados, que constroem, intersubjetivamente, o mundo de que, em simultâneo, falam. O significado emerge, assim, da própria dinâmica das interações humanas e não é redutível ao domínio representativo-referencial. Ao falarem, os falantes não descrevem apenas o mundo, agem sobre ele, constroem-no, e inscrevem-se subjetivamente nos seus discursos, veiculando assim outros níveis de significado, mais subtis, mas não menos importantes: significados acionais $^{80}$, interpessoais, argumentativos ou, dito de forma mais abrangente, significados de natureza pragmática. ${ }^{81}$

\section{Linguística e Direito}

Partindo do quadro atrás delineado, compreende-se o interesse que a Linguística vem demonstrando pelos contextos socioprofissionais, contextos em que a linguagem e os discursos são usados para dar consecução a determinadas funções institucionais. ${ }^{82} \mathrm{E}$ o domínio do Direito não

${ }^{80}$ A noção de que falar é agir, praticar uma ação, tem constituído uma ideia central da Linguística contemporânea e, mais concretamente, das correntes pragmáticas.

${ }^{81}$ Utilizamos esta expressão para designar o significado que é veiculado por um enunciado produzido (e interpretado) num contexto particular.

82 Ver, sobre este assunto, Coulthard, M. and Johnson, A., 2010: 8. 
constitui exceção. Tiersma (1993) já observara que: "Few professions are as concerned with language as is the law." A linguagem tem mesmo um papel estruturante neste domínio, pois quer a área da legislação, com o seu conjunto de documentos linguisticamente codificados que regulam todos os aspetos da nossa vida quotidiana, quer o âmbito judiciário, desde a investigação policial até ao decurso das audiências, não poderiam funcionar sem recorrer à instrumentalidade da linguagem. Por isso, e no mesmo sentido das observações anteriores, Gibbons (2003: 1) afirma: "The law is an overwhelmingly linguistic institution."

Mas as possíveis articulações entre a linguagem e o universo jurídico não se esgotam nos pontos atrás elencados. A lei - e mais propriamente a linguagem em que ela se encontra formulada - determina todos os nossos comportamentos em sociedade; no entanto, nem todos ou quase ninguém excetuando os profissionais da área - a conhecem ou, dito de outra forma, nem todos a ela têm acesso, uma vez que aquilo que a linguagem da lei nos comunica nem sempre é muito inteligível. Por outro lado, estas dificuldades comunicativas não se cingem à interação entre o domínio da Lei e os cidadãos, pois na vida quotidiana são também frequentes os equívocos e as ambiguidades gerados pelas palavras e pelos discursos. Muitos destes equívocos podem até chegar à sala de audiências e, uma vez mais, temos a linguagem a assumir o papel central no âmbito judiciário: ela pode tornar-se o próprio objeto de litígio, sempre que é necessário aferir, com rigor, o significado de uma expressão que se encontra no centro de um processo judicial ou a autoria de um texto que é fundamental para a decisão de um caso.

\subsection{Linguística Jurídica}

Dada a evidência destes pressupostos, cunhou-se o termo Linguística Jurídica (ou Forense ${ }^{83}$ ) para designar a interseção das duas áreas e todos

83 A expressão Linguística Forense foi usada, pela primeira vez, em 1968, pelo linguista Jan Svartvik, aquando da sua análise linguística das alegações proferidas por Timothy John Evans, enforcado pelo homicídio da sua mulher e da sua filha. 
os subdomínios que, relevando do Direito, podem constituir objeto de estudo das ciências da linguagem.

A abrangência das temáticas que podem integrar esta macroárea, de natureza interdisciplinar, é grande, como se verifica se atentarmos na listagem das seguintes disciplinas: interpretação e tradução em contexto judiciário; análise dos direitos linguísticos; questões de fonética forense; legislação sobre línguas e linguagem; o linguista como testemunha pericial; o crime linguístico; a deteção de plágio; a redação legislativa; a comunicação em sala de audiências; a identificação da autoria de um texto ou discurso; a interação com testemunhas vulneráveis (crianças e deficientes); a formação linguística dos profissionais do Direito; os géneros discursivos em sala de audiências, etc.

Embora a expressão Linguística Jurídica constitua, pois, um termo abrangente que recobre todas estas e muitas outras áreas de estudo ${ }^{84}$, ou seja, todas as articulações entre a linguagem, o discurso e o Direito, é usual subsumir estes diferentes tópicos em duas ou três grandes linhas de investigação. Por um lado, e segundo muitos autores, o campo de trabalho pode direcionar-se para a análise do texto legal escrito, a chamada "law in books" e, por outro, pode tomar como objeto de estudo os procedimentos linguísticos, eminentemente orais, do âmbito judiciário ou aquilo que alguns designam por "law in action". Esta bipartição do campo de estudos da Linguística Jurídica converge, como é óbvio, com a tradicional distinção linguística entre a modalidade oral e a modalidade escrita; porém, é útil lembrar que, pelo menos no domínio do Direito, não é fácil delinear uma fronteira precisa entre a linguagem / o discurso da legislação e a linguagem / o discurso do fórum. ${ }^{85}$ De facto, o universo jurídico repousa, em grande medida, na palavra escrita, e mesmo nos casos em que a oralidade se reveste de suma importância, como na audiência, o discurso oral que aí ocorre tem de sujeitar-se a uma orgânica relativamente

84 Outros possíveis domínios de investigação são apresentados, por exemplo, em Levi, J. and Walker, A. G., 1990: 11 e Olsson, J., 2004: 4-5.

85 E não o é também, obviamente, no domínio da própria linguagem, em que algumas das novas tecnologias vieram baralhar um pouco essa distinção. 
rígida, elaborada e pré-definida ${ }^{86}$, e não é fácil isolá-lo de todo o processo legal (escrito) que o antecedeu e que lhe serve de enquadramento. ${ }^{87} \mathrm{Se}$ a oralidade é o principal modo de comunicação em sala de audiências, esse oral está, em permanência, "intertextually linked and contextualised by a whole array of written texts: statutes, the police caution and other written texts." (Coulthard and Johnson, 2010: 3)

Tomando em conta esta objeção, outros investigadores apontam para uma diferente repartição dos campos a investigar: a linguagem jurídica e este rótulo abarcaria quer a análise do texto legal escrito quer a do discurso oral em sala de audiências - e a linguagem como elemento de prova, envolvendo este subdomínio o trabalho pericial do linguista. ${ }^{88}$

Uma outra proposta de trabalho, mais recente, retoma a já clássica divisão inicial entre texto legislativo e discurso em sala de audiências e adiciona-lhe a área da prova linguística em Tribunal. ${ }^{89}$

\section{Os atos de comunicação na legislação}

Independentemente da pertinência destas subdivisões e uma vez contextualizado o campo de estudos, o presente texto pretende, agora, tendo em conta a temática do Colóquio, centrar-se na dilucidação de algumas questões inerentes ao processo de comunicação que podemos encontrar no âmbito jurídico e, mais concretamente, na área do texto legislativo.

O universo do Direito, sendo um universo de palavras e de discursos, consubstancia-se numa miríade de atos de comunicação. A comunicação entre o universo jurídico e os cidadãos processa-se, antes de mais, através da legislação. Entendemos por 'texto legislativo' um vasto conjunto de documentação legal escrita, que sustenta e constitui o ordenamento jurídico de um determinado Estado. Leis, decretos-lei, portarias e despachos constituem

\footnotetext{
${ }^{86}$ Ver Carapinha, C., 2006: 206.

${ }^{87}$ Idem, ibidem, pp. 71.

${ }^{88}$ Esta divisão é proposta por M. Coulthard e A. Johnson, na sua obra de 2007.

89 Esta tripartição surge já em Gibbons e Turell, 2008, mas também é defendida em Coulthard e Johnson, 2010.
} 
apenas alguns exemplos, entre outros princípios, normas e regulamentos com valor legal. Estes géneros legais existem para ordenar as relações humanas em sociedade, o que inclui não só as normas de natureza reguladora que permitem restabelecer a ordem social quando esta é violada, mas também as normas constitutivas que permitem a criação de vínculos e relações jurídicas entre entidades. Estes dois tipos de normas consubstanciam, assim, dois grandes objetivos comunicativos do texto de lei: um de natureza diretiva, levando os recetores a agir de uma certa forma (a lei proíbe ou permite certo tipo de atos) e outro de natureza performativa (a lei tem a capacidade de criar realidades novas). ${ }^{90}$ Isto significa que a Lei - entendida aqui num sentido hiperonímico, isto é, como termo abrangente no âmbito do qual cabem muitos géneros distintos ${ }^{91}$ - comunica connosco sob variadas formas, ou seja, produz diferentes atos de comunicação dirigidos aos cidadãos. Será essa comunicação clara, objetiva, compreensível?

\subsection{Legislação - uma comunicação inteligível? 92}

A codificação linguística dos conceitos jurídicos, trabalho do legislador93, é uma tarefa complexa. Em primeiro lugar, porque os conceitos jurídicos se revestem, na esmagadora maioria dos casos, de uma tal complexidade cognitiva que não é fácil verbalizá-los 94 ; em segundo lugar,

90 Esta divisão entre objetivos de natureza diretiva e performativa é demasiado simplista e exigiria um outro desenvolvimento que, todavia, não é compaginável com o teor deste texto.

91 Para facilitar a exposição, partimos do pressuposto de que o texto legislativo constitui uma totalidade homogénea. Todavia, é pertinente lembrar que, sob esta designação, cabem géneros legais muito distintos, certamente caracterizados por diferentes estilos de redação. Ver, por exemplo, Brkić, J. e Anderson, N. 1988: 87. Ver também Dubouchet, P. 1990: 192. Ver ainda Bhatia, V., 1994: 138-140. E também Jackson, B. 1995: 112.

92 Para a redação do presente texto, partimos, apenas, da análise dos Códigos Civil e Penal. Não cremos, todavia, que a exiguidade do corpus falseie ou enviese as conclusões a que aqui chegamos. Apesar de a legislação se consubstanciar num amplo e diversificado conjunto de documentos, julgamos que a caracterização aqui efetuada se aplica a grande parte desta documentação (embora, com certeza, não à generalidade).

93 O termo 'legislador' permite-nos referir, de forma cómoda, essa entidade que, como veremos na sequência da exposição, não conseguimos identificar com rigor.

${ }^{94}$ E essa complexidade de redação gerará sempre grandes dificuldades à interpretação leiga. 
e sem que estas duas ordens de razões sejam mutuamente exclusivas, porque é essencial ponderar, em permanência, o equilíbrio entre a fiabilidade e a precisão jurídicas, necessárias à definição de conceitos determinados, e a indispensável maleabilidade do sistema legislativo, que o torna apto a adequar-se a inúmeras e variadas instâncias. Esta contínua tensão entre a procura da flexibilidade e da precisão linguísticas tem, obviamente, efeitos no texto de lei. ${ }^{95}$ A linguagem legislativa revela, com frequência, um vocabulário específico e um modo de dizer particular que a afastam dos usos comuns da língua. Este domínio do saber, tão especializado, foi sujeito, ao longo de séculos, a um processo de sistematização nocional, acompanhado de um processo de depuração e aperfeiçoamento linguísticos, e por isso se tornou um conteúdo de grande complexidade conceptual, quase sempre denso, e não raro dotado de alguma opacidade. Não são de estranhar, pois, as dificuldades reveladas pelos leigos na leitura desses textos.

A materialização linguística e discursiva destes traços é facilmente apreensível após uma brevíssima análise dos planos lexical, morfológico, sintático-semântico e textual do texto legislativo. 96

\subsection{Análise de traços linguístico-discursivos}

Do ponto de vista lexical, podemos salientar a ocorrência de lexemas que exprimem noções jurídicas precisas e que não encontramos nem em outras áreas do saber nem no fundo comum da língua. Anticrese e comodato constituem apenas dois exemplos desses termos técnicos que abundam no texto legal. A par destes lexemas, é também de assinalar a presença de palavras que, hauridas da variedade comum, ganham na variedade jurídica um significado novo e/ou mais preciso, como acontece com os exemplos seguintes: ação, autor, citação, vício e o par de palavras

\footnotetext{
95 Ver Tiersma, Peter M. 2000: 81.

96 Os exemplos ilustrativos de cada um dos níveis de análise linguística foram retirados dos Códigos Penal e Civil do Direito português. Ver, supra, nota 92.
} 
furto / roubo. ${ }^{97} \mathrm{Um}$ outro traço significativo diz respeito à abundante presença de expressões de origem latina e grega no texto de lei: corpus delicti; habeas corpus; de jure; anatocismo; sinalagmático.

Em termos morfológicos, evidencia-se o elevado número de nominalizações ${ }^{98}$ que perpassa na legislação; esta categoria sintática revela-se duplamente útil, por um lado porque o Direito necessita de nomear conceitos, figuras e relações jurídicas, na sua premente urgência definitória e por outro, porque a economia de meios linguísticos assim obtida facilita a comunicação precisa entre os especialistas. Eis alguns exemplos: perfilhação; arresto; suprimento; privilegiamento; concausalidade; impenhorabilidade; imprescritibilidade.

Antes de passarmos à análise dos outros dois planos, importa enfatizar que, no geral, o texto legislativo apresenta um conjunto de expressões de grande rigor concetual que configuram um campo de especialidade, facilitando a comunicação intraprofissional. Porém, quando equacionados do ponto de vista do leigo, verificamos que estes traços - a tecnicidade, a precisão semântica, o recurso às línguas clássicas, o caráter culto desta variedade, o elevado número de nominalizações, acrescido do elevado número de sílabas de algumas palavras - acabam por exigir-lhe um grande esforço cognitivo no processamento deste tipo de informação.

Se analisarmos agora o nível sintático-semântico destes textos, um dos dados que mais se salienta é a ocorrência de frases muito extensas ou, como variante deste traço, a existência de frases concetualmente muito complexas e, portanto, de difícil inteligibilidade. Consideremos apenas um exemplo:

Art. $8300^{\circ}$ 4. do Código Civil - Tratando-se de promessa relativa à celebração de contrato oneroso de transmissão ou constituição de direito real sobre edifício, ou fração autónoma dele, em que caiba

97 Greimas já havia chamado a atenção para esta peculiaridade do discurso legal que faz transitar, do fundo comum da língua para o código fechado da variedade legal, palavras e significados que submete a uma transformação ou correção semânticas rigorosas. Ver Greimas, A. J. 1976: 79-128.

98 A nominalização constitui um processo morfológico que permite formar nomes (substantivos), a partir de diferentes classes de palavras. 
ao adquirente, nos termos do artigo $721^{\circ}$, a faculdade de expurgar hipoteca a que o mesmo se encontre sujeito, pode aquele, caso a extinção de tal garantia não preceda a mencionada transmissão ou constituição, ou não coincida com esta, requerer, para efeito da expurgação, que a sentença referida no $\mathrm{n}^{\circ} 1$ condene também o promitente faltoso a entregar-lhe o montante do débito garantido, ou o valor nele correspondente à fração do edifício ou do direito objeto do contrato e dos juros respetivos, vencidos e vincendos, até pagamento integral.

Se, de um certo ponto de vista, estas características visam uma redação legislativa clara, precisa e não ambígua, e se constituem uma forma de comunicação mais rápida e objetiva entre os profissionais, por outro, oneram o trabalho interpretativo do leigo e geram problemas de inteligibilidade.

Sendo, por definição, uma linguagem cautelar, a legislação apresenta uma sintaxe mais propensa à definição analítica, à explicação exaustiva e rigorosa dos conceitos do que às sínteses objetivas e simplificadoras; neste sentido,a sintaxe legislativa caracteriza-se também pela justaposição de lexemas, aparentemente sinonímicos, que, em sequência, tentam dar conta do maior número possível de casos, de condições, de circunstâncias, enfim, de instâncias. Veja-se o exemplo seguinte:

Art. 275. ${ }^{\circ}$ 1. do Código Penal - Quem importar, fabricar, guardar, comprar, vender, ceder ou adquirir a qualquer título, transportar, distribuir, detiver, usar ou trouxer consigo engenho ou substância explosiva (...), é punido com pena de prisão até 3 anos ou com pena de multa.

No que tange ao plano textual, é visível a preocupação do legislador em tornar o seu texto uma unidade autónoma, organizando-o localmente de forma a dar consecução a essa globalidade significativa. Isto significa que a estruturação interna dos Códigos, por exemplo, com as suas compartimentações em livros, títulos, capítulos, secções, subsecções, artigos 
e alíneas não só evidencia, uma vez mais, o espírito de especialização e de subespecialização subjacente ao Direito, como também comprova a existência de uma certa autonomia de cada uma dessas divisões que deve ser inteligível por si mesma. ${ }^{99}$ A escassez de mecanismos coesivos ${ }^{100}$ neste texto joga precisamente a favor da não ambiguidade e da autoexplicitação e constitui evidência de que o texto de cada uma destas divisões se apresenta como sintática e semanticamente independente, assegurando assim a sua própria interpretabilidade. ${ }^{101}$

Esta análise dos traços linguísticos que tipificam alguns documentos legislativos não pode, todavia, ser dissociada das condições que configuram o quadro enunciativo em que este discurso é gerado; de facto, as características exibidas pelo discurso legislativo ganham plena justificação se considerarmos o locutor que o produz, as circunstâncias em que é redigido, o interlocutor a quem se dirige e os objetivos comunicativos que persegue.

\subsection{O quadro enunciativo do texto de lei}

Se atentarmos no contexto constitutivo de qualquer ato de comunicação, surgem como elementos fundamentais o locutor, o interlocutor e o espaço-tempo da interação, naquilo que podemos considerar o contexto situacional estrito no âmbito do qual essa comunicação se processa.

99 Apesar desta evidência, é pertinente recordar que muitos textos legislativos estabelecem remissões internas, isto é, referem outros textos que são, muitas vezes, inacessíveis ao leigo e/ou que remetem ainda para outros textos, o que torna a apreensão imediata e global da informação quase impossível.

100 Referimo-nos aqui ao conjunto de estratégias linguísticas que permitem interligar e relacionar diferentes partes de um texto, como por exemplo, as expressões anafóricas e os conectores. É de notar, todavia, a presença de tais mecanismos no interior das mais pequenas subdivisões dos Códigos, como se pode atestar através da observação do penúltimo exemplo (Art. 830. ${ }^{\circ}$ 4. do Código Civil) em que encontramos várias expressões anafóricas ('dele'; 'o mesmo'; 'aquele'; 'esta'; 'lhe'; 'nele'). Tal comprova, uma vez mais, a autonomia sintática e semântica de cada uma destas subdivisões.

101 É aquilo que Goodrich apelida de "unity and closure of legal discourse." Ver Goodrich, P., 1987: 169. 


\subsubsection{O locutor}

No atinente aos participantes envolvidos neste ato de comunicação, a primeira interrogação a fazer recai sobre o sujeito enunciador do discurso legislativo: quem é o legislador? Poderemos identificar um sujeito específico como o produtor deste discurso? A discussão dos temas e a subsequente redação escrita dos textos cabem à Assembleia da República, e respetivas comissões parlamentares, bem como ao Governo. Por outro lado, a tramitação processual seguida pelo texto legal obriga-o a passar pelo crivo de uma série de órgãos até ao momento da promulgação. É, pois, quase impraticável o reconhecimento desse redator primeiro e original. Assim, estamos perante uma entidade coletiva, sem um rosto individualizável, que fala em nome do poder legislativo, que é porta-voz do Estado, no fundo, que representa todos os cidadãos. ${ }^{102}$ A heterogeneidade de vozes que se cruzam na produção deste discurso e a complexidade processual que se encontra na sua génese conjugam-se e traduzem-se numa série de características por ele apresentadas.

Por um lado, a diluição e o apagamento da instância emissora - convergente com a tese defendida por Ducrot de que alguns tipos de texto institucional parecem não ter origem numa subjetividade particular ${ }^{103}$ explicam a impessoalidade que perpassa neste texto, visível no elevado número de ocorrências de estruturas passivas, na presença de construções impessoais, na escassez de formas verbais do modo pessoal. Por outro lado, esta marcada ausência de subjetividade casa bem com esse compósito de vozes, irreconhecíveis na sua individualidade e que,

102 Eis-nos, pois, perante um discurso que procede de uma entidade real, embora inidentificável, e que manifesta certamente outras vozes, outros discursos, e esta polifonia (compósito de vozes), dá conta da marcada plurivocidade que caracteriza a sua génese. Assim, é evidente, que estamos aqui perante um caso exemplificativo da já clássica distinção entre sujeito falante - uma entidade do mundo real, com determinadas características físicas, psíquicas e sociais - e entidades teóricas tais como o locutor e o enunciador, seres do discurso, responsáveis pela enunciação e pelos objetivos comunicativos que ela carreia, respetivamente. Sobre este assunto, ver Ducrot, O., 1984: 189-195 e 199-209.

103 Ver Ducrot, O. 1982: 75-76. 
ao longo do tempo, das sucessivas reformas, revisões e reformulações legais foram modelando os textos de lei e afastando o seu 'produtor' dos potenciais recetores. Cabe ainda assinalar que esta distância estabelecida entre o locutor-enunciador e a sua plateia é concomitante com a descontextualização do texto legislativo. As situações previstas nos documentos legais nunca se encontram ancoradas a um espaço-tempo particular e configuram, antes, situações-tipo; de igual modo, as entidades referidas nunca designam um referente único e específico, autorizando apenas uma interpretação de natureza genérica. A despersonalização e o maior grau de abstração implicado por esta desancoragem espácio-temporal, conseguidos pela redação legal, são quase sempre incompatíveis com a desejável clareza de estilo que garantiria, ao leigo, uma interpretação sem sobressaltos.

Mas há que considerar a existência de um interlocutor para este texto. Quem é o recetor do texto legislativo? Os profissionais do Direito? Ou todos os cidadãos cuja conduta é regulada por essa mesma legislação? A resposta a esta pergunta não é fácil e exige algumas considerações que irão retomar alguns dos pontos atrás aflorados, bem como a questão da contextualização e dos objetivos comunicativos deste discurso (com que iniciaremos, aliás, o ponto seguinte).

\subsubsection{O contexto}

O objetivo da lei é predispor para o futuro, ou seja, regulamentar o comportamento do cidadão para um intervalo de tempo sempre posterior ao da sua redação e promulgação. Por isso, o legislador prefere enunciados gerais, atemporais que se esquivam a uma ancoragem precisa. $O$ termo 'telelinguagem', de que fala Cornu (2000: 291), caracteriza precisamente este discurso à distância, apto a ser lido e interpretado por qualquer um, em qualquer situação futura. Pretendendo abranger o maior número possível de instâncias, e tentando ser o mais preciso e exaustivo possível, o legislador encontra-se perante um dilema que não é de fácil resolução. Por um lado, tem de dar consecução ao desiderato da clareza, da certeza 
e do rigor jurídicos ${ }^{104}$, e não é por acaso que recorre aos lexemas técnicos, específicos da especialidade, e que grande parte dos enunciados legais tem um carácter definitório, estratégia de natureza lexicográfica que estabelece - e legitima - sentidos específicos ${ }^{105}$. O rigor conceptual assim obtido tem de adaptar-se, todavia, a todos os casos supervenientes ou, pelo menos, ao maior número possível e, neste sentido, o texto de lei tem de mostrar flexibilidade, adaptabilidade. ${ }^{106}$ A necessidade de 'all-inclusiveness', como lhe chama Bhatia (1993: 103), isto é, a tentativa de abarcar todas as contingências e, no fundo, juridificar cada parcela da realidade parece, pois, obrigar a um maior grau de generalização, contrariar a precisão anteriormente referida e gerar um (pelo menos aparente) paradoxo: quanto mais abrangente a regra pretender ser, menor será a especificidade do seu conteúdo.

Neste sentido, é bem conhecida a indeterminação e a vagueza que pontuam em muitos textos, em muitas definições e que deixam na legislação um halo de ambiguidade e de imprecisão, à partida, inesperadas. ${ }^{107}$ Porém, o legislador vê-se, não raro, confrontado com a necessidade de recorrer àquilo que os juristas apelidam de 'conceitos indeterminados' e de 'cláusulas gerais'. ${ }^{108}$ Porquê? Em primeiro lugar, porque estas expressões são, por vezes, as únicas que obtêm um consenso político-jurídico alargado. ${ }^{109}$ Por outro lado, o recurso a esta formulação mais

104 Em Bhatia (2010: 37-50) encontramos uma análise aprofundada das quatro características que todo o texto legislativo deveria ter: clareza, precisão, não ambiguidade e especificidade de conteúdo.

105 Jackson (1995: 138) afirma até que "The law (...) is a set of technical concepts, related to each other in a particular system of signification."

106 Ver, supra, o item 3.1.

107 Já na década de 40 do séc. xx, William Glanville apontara este traço do texto legislativo. Ver Glanville, Williams, 1945.

108 Machado, 2002: 57.

109 A este propósito, leia-se a resposta de Nelson Jobim, ex-Ministro da Justiça e, ao tempo, presidente do Supremo Tribunal Federal (STF), quando questionado acerca das lacunas existentes na legislação: "A aprovação da lei depende da ambiguidade do texto. Quando fui deputado, o doutor Ulysses Guimarães (presidente da Assembleia Constituinte) pedia para eu escrever os artigos da Constituição. Eu mostrava para ele o texto tecnicamente perfeito, sem brechas. Mas aí o texto só tinha $20 \%$ dos votos. Então eu redigia outros textos, aumentando o nível de ambiguidade, até chegar no ponto do acordo. Faz parte do 
geral e indeterminada evita as dificuldades inerentes a uma redação mais minuciosa e particularizante. ${ }^{110}$ Ainda é possível justificar a utilização desta estratégia se pensarmos que grande parte das normas jurídicas configura um sistema fechado, dotado de 'certeza jurídica', relativamente rígido e preciso. Ora, torna-se necessário contrabalançar, muitas vezes, esta rigidez do texto legislativo, dotando-o de uma certa dose de adaptabilidade e de flexibilidade, de modo a acomodar os ordenamentos jurídicos à dinâmica das realidades sociais, em permanente transformação. Os termos vagos, os conceitos indeterminados, e todas as expressões que, de certa forma, consubstanciam a incompletude do texto legislativo podem, assim, ser positivamente perspetivados. E não deixa de ser curioso que estes traços semânticos sejam até perseguidos pelo legislador ${ }^{111}$; nas palavras de Machado (2002: 120), eles constituem não um "acidente mas uma componente estrutural do sistema jurídico."112

Mas há ainda um outro traço que caracteriza este contexto comunicativo e que pode justificar algumas das características encontradas no texto legislativo.

Note-se, para começar, que não estamos perante um contexto comunicativo típico em que os participantes partilham um contexto situacional comum; como já foi anteriormente referido, o texto legislativo é redigido num tempo que pode ser muito apartado do tempo em que o recetor o profissional do fórum - vai aplicar essa mensagem a uma instância específica; mais, o texto legislativo encontra-se desancorado de qualquer contexto particular e concreto e não foi pensado para um caso singular. Esta dilação temporo-contextual pode ser, em certa medida, contrabalançada pela cultura legal supostamente partilhada pelo legislador

jogo democrático." (In: Jornal O Globo, 07.07.2004, apud: http://www.facape.br/anderson/ ied/A_linguagem_no_Direito.pdf)

110 Christie afirma até que os conceitos de difícil definição não devem ser sujeitos a grande explicitação, pois tal dissecação traria mais problemas que esclarecimentos. Ver Christie, George C., 1964: 901.

111 Lawrence Friedman (1964-1965: 572) afirma, a este propósito: "Vagueness is sometimes a deliberate tool of the law-maker."

112 Galvão Telles apelida-os de "órgãos respiratórios do organismo jurídico" e de "válvulas de segurança”, (2000: 147). 
e pelo julgador - ao partilharem estudos, experiências, conhecimentos e contextos de trabalho, potenciais dificuldades de interpretação podem ser minimizadas. Apesar desta atenuante, temos de equacionar ainda, todavia, o facto de esta comunicação nem sempre ser uma comunicação genuinamente cooperativa. ${ }^{113}$ Ao contrário do que ocorre nas nossas interações verbais quotidianas, de natureza formal ou informal, em que os participantes estão imbuídos de um espírito de cooperação que guia a sua conduta conversacional no sentido de otimizar o uso da linguagem, no contexto da comunicação legislativa, e dada a forma como o texto legislativo é gerado, nem sempre a informação explicitada na lei é a mais clara, a mais precisa, a mais objetiva, ou seja, nem sempre o texto legislativo segue a Máxima de Modo que prevê a evitação da obscuridade e da ambiguidade. ${ }^{114}$ Muitas vezes, como já vimos, a redação legislativa resulta de consensos políticos dificilmente obtidos, de ações estratégicas concertadas no sentido de obter cooperação entre os agentes envolvidos e pode ser propositadamente vaga e lacunar. ${ }^{115}$ Por outro lado, e agora sob um outro ponto de vista $^{116}$, dado que essa comunicação é sempre à distância, o legislador não pode prever, por antecipação, toda a informação, toda a explicitação, toda a especificidade necessárias a uma interpretação contextualizada e posterior, isto é, ele nunca saberá (a não ser a posteriori) se o texto que redigiu é excessivamente informativo ou, pelo contrário, escassamente informativo. Por outras palavras, ele pode tentar dar consecução à Máxima da Quantidade ${ }^{117}$, segundo a qual, o seu contributo deve ser tão informativo quanto o necessário para o ato de comunicação, mas não conhecendo

113 Estamos a lidar aqui com um dos princípios reguladores da interação discursiva, o Princípio da Cooperação (integrando as quatro Máximas Conversacionais que o especificam) proposto por Grice. Ver Grice, P., 1975: 41-58.

114 A Máxima de Modo é uma das quatro Máximas em que se desdobra o Princípio da Cooperação. Ver nota anterior.

115 Ver Marmor, 2008: 136.

116 Note-se que estes dois pontos de vista encontram-se intimamente imbricados um no outro, na medida em que a redação legislativa pode visar, propositadamente, a obtenção de um certo grau de indeterminação para que o poder judiciário venha a decidir "conforme as circunstâncias do caso e as modificações trazidas pela evolução social." (Machado, 2002: 57)

117 Outra Máxima Conversacional que concretiza o Princípio da Cooperação. Ver, supra, notas 113 e 114 . 
de antemão o contexto em que a 'sua' lei vai ser interpretada e aplicada, ele não pode adivinhar qual o grau de especificidade informativa necessária à sua aplicabilidade a instâncias concretas. E também por esta via a comunicação pode não ser efetivamente cooperativa.

\subsubsection{O interlocutor}

Retomemos, então, a questão relativa ao recetor do texto legislativo. Não tendo um autor histórico identificável, este texto parece não ter, também, um destinatário particular e específico; o recetor é constituído pela coletividade para a qual o texto ganha força de lei.

Já vimos que a lei pode ser entendida como regra de conduta geral e abstrata: geral, porque ela nunca se dirige a uma entidade única, mas a um amplo conjunto de destinatários; abstrata, porque não pretende abranger um caso específico, mas um conjunto de casos. ${ }^{118}$ Assim concebida, percebemos que a lei, quer na sua vertente preceptiva, quer na sua vertente proibitiva, quer ainda na sua vertente permissiva ${ }^{119}$, deveria materializar-se num texto formulado de modo genérico, mas suficientemente claro e preciso para não deixar dúvidas e incertezas ao interpretante. Todavia, e podemos equacionar aqui os dois interpretantes possíveis - o profissional e o leigo - será que esse desiderato é exequível?

\subsubsection{O interlocutor profissional}

Por um lado, o juiz tem de interpretar a lei ao aplicá-la a um contexto (a uma instância) único e específico; enquanto noutros discursos, até mesmo profissionais, pode haver uma margem de variabilidade interpretativa,

118 Ver Machado, p. 91-93.

119 Usamos aqui os termos apresentados por J. B. Machado (2002: 93-94). E lembramos que esta tripartição é consistente com a classificação apresentada pela lógica modal deôntica, o ramo da lógica centrada nos conceitos normativos, ou seja, nas noções de 'obrigação/ dever', de 'proibição' e de 'permissão'. 
tendo em conta o contexto e as suas variáveis, o texto legislativo é avesso a interpretações contingentes: independentemente dos participantes e das suas circunstâncias, ele visa uma interpretação sistemática, consistente, uniforme. De acordo com Galvão Telles (2000: 145), as normas jurídicas "na sua grande maioria, assumem carácter por assim dizer rígido: são de aplicação automática. Estão gizadas para um facto bem determinado: não há senão que aplicá-las nos seus precisos termos quando se suscitem as situações nelas previstas." Ora, será isto sempre possível? Será a norma jurídica tão objetiva que se possa reduzir a uma formulação lógica do tipo: se $\mathrm{X}$, então $\mathrm{Y}$ ? E nos casos em que o juiz se encontra perante um texto, um artigo ou uma alínea formulados de modo vago, em que a lei não é suficientemente clara e específica de modo a permitir ao profissional uma interpretação unívoca? Ou, olhando o fenómeno sob um ângulo diferente, e nos casos em que as características do contexto geram dúvidas quanto à aplicabilidade de uma determinada lei? Não terá o poder judiciário de interpretar - contextualmente, casuisticamente - a intenção do legislador? Não serão os tribunais obrigados a exercer uma certa atividade 'legislativa' em resultado da incompletude da própria lei? ${ }^{120}$ É impossível tudo juridificar, sobretudo em alguns ramos do Direito. E é o mesmo autor que afirma: "O Direito não se ajusta adequadamente à vida se pretende aprisioná-la e torná-la rígida. A vida é muito mais forte do que o legislador e vinga-se, a cada passo, quando ele julga tê-la nas mãos"121, por isso nem sempre a subsunção dos factos concretos a um tipo particular de enquadramento legal é um processo imediato, automático, racional, silogístico (se é que alguma vez o é). A compreensão do texto da lei ou, em termos jurídicos, a interpretação da lei constitui um primeiro passo num processo complexo

120 Tenha-se em devida conta o Direito inglês e, em geral, o Direito dos países em que vigora a Common Law. Este ordenamento jurídico, vigente nos países anglófonos (aqui incluindo também as antigas colónias do império britânico como a Índia e Hong-Kong, por exemplo), toma como fonte de Direito o precedente, ou seja, o conjunto de todos os julgamentos anteriores relevantes, que lidaram com casos similares, e que passam a valer como regra jurídica a ter em conta. No sistema jurídico português, de natureza diferente, o precedente não tem poder vinculativo. Veja-se, todavia, o caso dos Assentos proferidos pelo Supremo Tribunal de Justiça.

121 Galvão Telles, I., 2000: 146. 
que envolve também outras fases: a esta apreensão que poderemos apelidar de 'semântica' do texto da lei sucede a captação do sentido da lei 'naquele' contexto particular, a componente mais pragmática do processo. E nesta aplicação da lei ao caso sub judice, ou seja, nesta vertente da comunicação no contexto legal algumas questões podem ser levantadas.

O texto de lei pode não comunicar, de facto, de forma clara e inequívoca com o poder judiciário. Aliás, pode até ocorrer um potencial conflito entre o poder legislativo e o poder judiciário: este pode, em última instância, decidir acerca da intenção originária do legislador - é a velha querela entre a letra da lei e o espírito da lei - mas o poder legislativo não deixa de tentar, até aos limites daquilo que lhe é possível especificar e juridificar, evitar essa discricionariedade do julgador. ${ }^{122}$

\subsubsection{2. $O$ interlocutor leigo}

Consideremos, agora, o processo de comunicação da norma jurídica com o recetor leigo. É certo que a maioria dos cidadãos não pesquisa, no conjunto dos textos de legislação, a norma jurídica escrita que lhe dará a informação pretendida. A pessoa que, sem preparação jurídica, tem de interpretar o texto legal recorre invariavelmente à mediação do profissional. Porquê? A resposta mais imediata e simples que se pode dar a esta pergunta é a de que o texto legislativo não está redigido para o cidadão comum ou, por outras palavras, a de que as características linguístico-discursivas exibidas por grande parte da legislação ${ }^{123}$ não são compatíveis com os níveis de literacia da maioria da população. A ideia de que é o nível de escolaridade do cidadão comum que deve aumentar

122 Note-se que o equilíbrio e a hesitação entre uma redação muito precisa, específica e rigorosa e uma redação mais abrangente e genérica equivalem a um caminhar no fio da navalha, pois ambas têm vantagens e desvantagens. Bhatia afirma até que "(...) whereas over-specification in legislative expression creates problems of comprehension, especially for the uninitiated readership, under-specification, on the other hand, creates an even more serious issue of transparency in the construction and interpretation of legislative intent." (2010: 38-39)

123 Vimos algumas dessas características no item 3.2. 
no sentido de lhe permitir aceder a práticas discursivas mais complexas tem sido enfatizada por grande parte dos profissionais legais que creem na eficácia da linguagem legal tal como está: prolixa e rebuscada sim, mas altamente especializada e, portanto, para eles, clara e funcional.

Todavia, o cidadão sem formação jurídica, ainda que com uma escolaridade mais alargada, continua a não ter acesso a grande parte da documentação legal precisamente porque ela exibe um baixo grau de compreensibilidade e porque, como afirma Stygall (2010: 61) "the entire knowledge domain is unfamiliar to lay readers." As palavras de Goodrich (1987:7) também são elucidativas a este respeito: "I have been intrigued by one of the major paradoxes of contemporary legal culture, namely that its social practice is founded upon an ideology of consensus and clarity - we are all commanded to know the law - and yet legal practice and legal language are structured in such a way as to prevent the acquisition of such knowledge by any other than a highly trained elite of specialists in the various domains of legal study." E não foi por acaso que nos países anglófonos surgiu uma corrente defensora do uso de um inglês claro e acessível - o Plain English Movement - originada pelo crescente desagrado dos cidadãos perante a linguagem incompreensível e obscura da esmagadora maioria da documentação oficial. ${ }^{124}$

É obvio que o desinteresse revelado pelo leitor leigo relativamente ao texto jurídico decorre, em grande medida, das dificuldades de leitura que ele suscita. ${ }^{125}$ Esse efeito de 'estranhamento', que os não-iniciados sentem quando contactam com o género legislativo, tem sido, aliás, apontado por diversos investigadores; dito de outra forma, as características da linguagem utilizada no texto de lei seriam geradoras de um ecrã linguístico que obstaculiza o processamento da informação subjacente. ${ }^{126}$

${ }^{124}$ Em Portugal, este movimento teve já repercussões e existe uma empresa dedicada à melhoria redatorial de muitos documentos provenientes de empresas e instituições: Português Claro. Informações úteis sobre esta empresa podem encontrar-se no sítio: http:// portuguesclaro.pt/

125 Como é evidente, haverá, com certeza, outras razões, de natureza diferente, que afastam os cidadãos da leitura do texto legislativo.

126 Ver Sourioux, J.-L. e Lerat, P., 1975: 10, 14, 18 e 57. Ver também Maley, Y., 1994: 11-13. Ver ainda González, D. F., 1997: 247. E ver Cornu, G., 2000: 19-20. 
Vejamos porquê. O processo de leitura e interpretação efetuado pelo leitor leigo parece apoiar-se, pelo menos na fase inicial, nas habituais estratégias cognitivas que ele usa na leitura e interpretação de outros tipos de texto: procura do domínio de referência, busca de dados já conhecidos nesse domínio, apreensão da informação nova e acomodação ou reajustamento dessa informação relativamente à informação já conhecida, processo que vai enriquecer esse mesmo universo de referência. Ora, ao contactar com o texto legislativo, o leigo encontra-se em terreno perfeitamente estranho: desconhece o domínio de referência e não possui quaisquer informações sobre ele; por outro lado, grande parte dos textos contém apenas informação completamente nova sem se estruturar de acordo com o expectável equilíbrio entre informação já conhecida, redundante - que sirva de âncora para o processo interpretativo - e informação nova, original. ${ }^{127}$

Assim, e ainda considerando todas as características linguístico-discursivas da norma jurídica - já anteriormente listadas - que dificultam e oneram o processo interpretativo, o leitor encontra-se não só perante textos de difícil inteligibilidade, mas também sem qualquer background cognitivo de apoio ao processamento daquela informação. Concordamos, pois, com Stygall, quando ela afirma (2010: 62): “The key process for lay readers then becomes working memory, previously called short-term memory."128 Todavia, a memória de curto prazo apresenta limitações várias quanto ao processamento de informação, nomeadamente quanto ao tempo - brevíssimo - de retenção de informações e à quantidade escassa - de dados informacionais que nela conseguimos reter nesses

127 Sabendo que qualquer texto veicula um determinado número de informações, o doseado equilíbrio entre informação conhecida e informação original constitui um dos pilares fundamentais para a sua existência como unidade textual. É o produtor do texto que, sabiamente, distribui as parcelas de informação já conhecida, assegurando a continuidade temática do mesmo, e que as articula com a informação nova, garantindo assim a progressão temática do texto. É o jogo entre estes dois princípios - 'continuidade temática' e 'progressão temática' - devidamente conjugados, que facilita a tarefa interpretativa do interlocutor. Se assim não acontecer, a tarefa interpretativa torna-se quase inexequível: por um lado, porque se tornaria monótono estar, em permanência, a processar informação sempre redundante; por outro, porque seria quase impossível estar a apreender informação sempre nova sem qualquer ponto de apoio prévio.

128 Negrito e itálico nossos. 
segundos e, uma vez mais, o leitor leigo encontra-se numa situação de desvantagem. ${ }^{129}$

\subsection{Uma redação - dois públicos}

$\mathrm{E}$ aqui retomamos as reflexões anteriormente avançadas, pois cremos que o cerne do problema reside precisamente no tipo de interlocutor visado. Há uma tensão irresolúvel no momento da redação legislativa, o que significa que o legislador parece não conseguir escrever para, isto é, comunicar eficazmente com duas audiências distintas. O cidadão comum e o profissional não partilham formação académica, não partilham experiência profissional, não partilham sequer o mesmo background cognitivo, e com isto queremos dizer que não partilham aquele conhecimento do mundo, armazenado na memória, que engloba um conjunto de representações prototípicas acerca de objetos, situações e sequências de eventos. Diferentemente designado por 'frame', 'script' ou 'schemata', este conjunto de saberes, intersubjetivamente partilhado pelos membros de uma determinada comunidade, funciona como um guião que os leva a organizar o pensamento e a ação de um modo consistente com essas conceptualizações. Ora, há divergências nítidas entre os scripts dos profissionais da lei e dos leigos - as estruturas cognitivas ou, dito de outra forma, os modelos socioculturais interiorizados por ambos os grupos não são coincidentes: os profissionais veem o mundo, conceptualizam-no através de categorias jurídicas muito precisas, claramente decorrentes da sua formação académica e tal não ocorre com o processo de categorização do mundo realizado pelos leigos.

Esta impossibilidade de chegar a dois públicos distintos leva o legislador a optar pelo óbvio: o seu texto destina-se, antes de mais e em

129 Por outro lado, e tendo em consideração a existência de outros fatores que afetam a operacionalidade desta capacidade cognitiva, tais como as situações de stress, não causará surpresa o facto de a tentativa de compreender um texto com um baixo grau de inteligibilidade gerar stress e contribuir ainda mais para a fraca performance da memória de curto prazo. 
primeiro lugar, ao poder judiciário, pois é este que, em última instância, o vai aplicar a uma infinidade de casos. É com este interlocutor que o legislador quer comunicar; é com ele que se esforça por ser cooperativo, e por isso redige um texto cujo objetivo primordial é a clareza, a precisão, a não ambiguidade, tentando evitar futuros e eventuais problemas de interpretação ao universo judiciário. Porém, tendo em conta todos os problemas de redação legislativa acima indicados, nomeadamente a questão do difícil equilíbrio entre fiabilidade e precisão jurídicas, por um lado, e a necessária flexibilização das normas jurídicas, por outro, não deixa de ser curioso notar que é justamente a procura incessante da precisão e do rigor (ou seja, a tentativa de se tornar maximamente cooperativo) que conduz, também, muitas vezes, a uma formulação linguística obscura, complexa, opaca. Vejamos o que Thornton diz a este respeito: "The purposes of legislation are most likely to be expressed and communicated successfully by the drafter who is ardently concerned to write clearly and to be intelligible. The obligation to be intelligible, to convey the intended meaning so that it is comprehensible and easily understood, (...) requires the unremitting pursuit of clarity by drafters. Clarity (...) requires simplicity and precision (...). The blind pursuit of precision will inevitably lead to complexity; and complexity is a definite step along the way to obscurity. (1996: 52-53)

Mais uma vez, e mesmo perante um só interlocutor, o legislador parece encontrar-se perante um círculo vicioso do qual é impossível escapar: para ser claro e inteligível, tem de ser preciso; ao tentar ser preciso, acaba por ser complexo; ao ser complexo, torna-se obscuro. Mas esta tentativa de minuciar o conteúdo da norma jurídica é consistente com o esforço do poder legislativo em evitar, na medida do possível, a discricionariedade do poder judiciário ou, por outras palavras, a possível (e eventual) discussão em torno do significado da norma. Como argumenta Hoey, o texto legislativo é redigido na assunção de que o seu sentido pode vir a ser contestado judicialmente. ${ }^{130} \mathrm{E}$ este pressuposto explica outro dos seus objetivos comunicativos: tentar acautelar esse possível litígio. Isto

130 Ver Hoey, M., 1985: 258. 
significa que o texto legislativo tem de procurar obter o maior grau possível de precisão, rigor e especificação, o que se faz sobretudo à custa da clareza e da simplicidade, para obviar a possíveis litígios e a eventuais interpretações contenciosas. Por isso, e de acordo com Brkić e Anderson (1988: 87), "Competent drafting of legal documents (...) must (...) take into account the existence of an interpreting audience, expected legal and non-legal consequences in case of compliance as well as noncompliance with the stipulations expressed in the documents. Indeed it must anticipate varying degrees and areas of possible compliance and noncompliance with the stipulations." Também Hoey (1985: 259) avança um argumento similar: "(...) the apparently convoluted syntax of legislative language is a product of the uncooperative reading it will encounter."

Ora, não deixa de ser interessante realçar esta imagem que o legislador constrói acerca do interlocutor do seu texto: um interlocutor que será, sempre, genuinamente não cooperativo. E, sob este ponto de vista, encontramo-nos, então, nos antípodas daquilo que ocorre na comunicação (verbal) do quotidiano. ${ }^{131}$ Aqui, todos os participantes estão imbuídos de um espírito de entreajuda que os leva a fazer um uso eficiente da linguagem: mesmo nos contextos em que parece faltar informação, em que parece haver descontinuidades ou quebras semânticas, em que parece que o dito não se encaixa bem no contexto, os falantes fazem um esforço cognitivo no sentido de procurar colmatar essas lacunas, de tentar encontrar pertinência para o que foi dito. Para isso, recorrem às informações linguísticas explicitamente obtidas e fazem as necessárias inferências, ou seja, constroem hipóteses interpretativas plausíveis, a partir dos dados contextuais disponíveis, da informação de background mutuamente partilhada, das suas enciclopédias e do conhecimento do mundo.

Ao invés, no âmbito da comunicação legislativa, parte-se do pressuposto de que o interlocutor não será cooperativo e de que tentará, por todos os meios ao seu alcance, fazer inferências indesejáveis, explorar sentidos imprevistos, minando esse princípio de boa-fé subjacente à coconstrução

131 Referimo-nos ao Princípio da Cooperação, atrás mencionado, no item 3.3.2. 
das nossas conversas quotidianas. E este constitui o móbil para uma redação complexa, minuciosa e exaustiva.

Este traço discrepante prende-se ainda com uma outra característica dos dois discursos: a sua diferente natureza dialógica. ${ }^{132}$

A cooperação e o comprometimento com 'o outro', o desejo de perceber o que ele efetivamente quis dizer e a tentativa de levar a bom termo o episódio conversacional, que ocorrem nos atos de comunicação habituais, do dia-a-dia, relacionam-se com a natureza intrinsecamente dialógica do discurso humano: os nossos discursos encontram sempre, de alguma forma, os discursos de outrem; nós falamos sempre para um outro, cuja presença pressentimos, com quem interagimos, cujas respostas antecipamos, com cuja cooperação contamos. ${ }^{133}$

Em franco contraste com essa comunicação verbal diária, a comunicação legislativa parece não estar alicerçada nesta atividade de cooperação linguística. Por outras palavras, embora estejamos perante um discurso em que ecoam vozes diversas (vejam-se as sucessivas reformas legislativas) ${ }^{134}$, em que se pressentem os enunciados de outrem (sobretudo os anteriormente produzidos sobre o mesmo assunto), perante um discurso que visa indubitavelmente um interlocutor futuro a cujas objeções tenta fugir por antecipação e, neste sentido, perante um discurso profundamente dialógico, por outro lado, o pressuposto da cooperação parece estar ausente desta comunicação. E encontramo-nos, então, face a uma conceção bastante mais estreita de dialogismo, uma conceção que envolve uma tessitura inextricável de vozes, mas não implica a cooperação entre os partícipes.

E não deixa de ser curioso verificar que esta mesma preocupação do legislador com a má-fé do interlocutor acaba por reunir, uma vez mais, as suas duas possíveis audiências. Os atos de comunicação legislativa

132 O conceito de 'dialogismo', com raízes em Bakhtin e Volochinov, designa não apenas as relações que um determinado discurso entretece com outros discursos atinentes à mesma temática, mas também as articulações que todo o discurso estabelece com os discursos a que vai dar origem (respostas, réplicas, refutações...).

133 Leia-se, a este respeito, o seguinte fragmento de Bres ... "(...) le locuteur s'adresse à un interlocuteur sur la compréhension-réponse duquel il ne cesse d'anticiper." (2005: 53)

134 Ver o que dissemos atrás, sobre o produtor - sem rosto - do texto legislativo, no item 3.3.1. 
partem da assunção, genérica, de que qualquer um dos seus interlocutores (o profissional e o homem comum) é capaz de explorar as lacunas da lei até ao limite do razoável, se com isso obtiver benefícios. Bhatia argumenta que a redação legislativa tem de combater "the age-old human capacity to wriggle out of obligations and to stretch rights to unexpected limits” (1993: 102), e daí a urgência de uma redação cautelar.

\subsection{Comunicação legislativa e autolegitimação}

É ainda pertinente considerar que esta inquietação do legislador com a receção do seu texto, que o leva a tentar responder, por antecipação, a eventuais lacunas, a hipotéticos e imprevistos sentidos, a inesperadas críticas e a eventuais reptos sobre a sua própria legitimidade de texto institucional, pode ainda revelar algumas - subtis - preocupações de autolegitimação. Não deixa de ser paradoxal que um texto investido de poder, em que se consuma uma imposição autoritária de regras e dirigido a todos os sujeitos de Direito acabe, pelo menos aparentemente, por evidenciar esta fragilidade: ele preocupa-se com as possíveis interpretações a que vai dar azo, com os múltiplos sentidos que dele serão hauridos, com a derrogação da sua intenção original.

Em conformidade com esta perspetiva, não é de estranhar, então, a forte presença, no texto legislativo, de segmentos definitórios e explicativos que visam definir conceitos e noções, apresentando significados muitas vezes exclusivos ao próprio Direito. Tal estratégia lexicográfica, associada ao facto de o texto legislativo tornar obrigatório e/ou verdadeiro aquilo que declara, permite ao Direito (e à lei) definir-se a si mesmo(a) e nos termos que lhe são mais convenientes, permite-lhe construir e delimitar significados, fornecendo aqui e ali instruções interpretativas claras, isto é, permite-lhe tentar impor as condições em que se vai processar a comunicação.

Sendo um texto definidor de sentidos e um texto que se autovalida,

o texto legislativo é, em certa medida, um texto demiúrgico, um texto criador de certas realidades que passam a impor-se como as únicas 
legítimas. ${ }^{135}$ Esta visão, crítica, da lei (discutível para muitos investigadores ${ }^{136}$ ), que a apresenta como um discurso que impõe determinados sentidos silenciando outros, que legitima determinadas categorizações do mundo em detrimento de outras, não pode ser dissociada de uma questão fundamental: constituirá a linguagem um instrumento de tradução linguística neutral e objetivo?

\section{A língua - 'apenas' um meio de comunicação? ${ }^{137}$}

Já vimos que a linguagem constitui o meio privilegiado, senão mesmo único, de expressão do universo jurídico e, mais concretamente, o meio de verbalizar a ideia jurídica que está subjacente ao texto legislativo. Será que a linguagem constitui apenas um meio de verbalizar, fiel e especularmente, essa ideia, que pré-existe ao discurso? Ou será que a ideia jurídica não tem existência autónoma e independente da sua formulação linguística? Até que ponto um conceito jurídico é (ou não) conformado através da linguagem que o expressa? Qual é o papel da linguagem no plasmar do conceito jurídico?

Eis-nos perante questões não despiciendas, e não é por acaso que os filósofos do Direito e os linguistas se têm ocupado delas. O papel desempenhado pela linguagem na nossa conceptualização do mundo tem vindo a constituir um amplo campo de pesquisa, quer para a Psicologia Cognitiva, quer para a própria Linguística Cognitiva.

No domínio jurídico, duas interrogações têm materializado esta reflexão. A primeira retoma uma das perguntas atrás arroladas: haverá conceitos jurídicos objetiváveis que não através da sua verbalização? A resposta

135 Ver, supra, o item 3. e a nota 90.

136 Para Hans Kelsen (autor do artigo: The Pure Theory of Law), por exemplo, e para todas as teorias legais de orientação positivista que excluem a consideração de todos os elementos subjetivos e historicamente determinados que 'contaminam' o sistema de normas.

137 Este item, bastante complexo, exigiria um desenvolvimento autónomo que, por razões óbvias, não pode caber no presente artigo. Fica, assim, ressalvada, a natureza fragmentária das reflexões e o escasso aprofundamento teórico que algumas delas aqui merecem. 
a esta questão não é consensual. Virally (1966: 13), em franca objeção às teorias de Amselek (1964), afirma que "La norme juridique, certes, ne peut être transmise (et sortir, par conséquent, des représentations purement subjectives) que si elle est objectivée, mais cette objectivation ne résulte pas nécessairement d'une formulation verbale." Defende o autor a ideia de que existem muitos conteúdos implícitos na lei, pelo que, na prática, um grande número de normas não é verbalizado, mas antes obtido através de raciocínio lógico ou de inferência, efetuados pelo interpretante. Opinião contrária a esta é revelada por Michel Villey no prefácio da revista Archives de Philosophie du Droit (tomo XIX). Aqui, o autor evidencia a importância desta faceta escondida da ciência do Direito: a linguagem não constitui apenas o meio de verbalizar todos os discursos do direito (o discurso da lei, o discurso do juiz, o discurso do jurista, o discurso da doutrina); todos estes discursos são condicionados pela linguagem e pelas suas características. "La langue est une servante-maîtresse. Et en vérité le langage est de lui-même connaissance; son vocabulaire, sa syntaxe sont une façon de penser le monde, de découper la structure du monde (...).” (Villey, 1974: 1)

A segunda interrogação permite-nos pensar, com Gibbons (1994: 3), na existência de conceitos jurídicos universais, ou seja, relativamente independentes da codificação legal a que são sujeitos em cada língua. Também aqui as opiniões divergem, pois o antropólogo Goldman (1994: 51-99) elenca alguns conceitos legais que parecem ser universais, ou seja, transversais a muitas línguas e que existiam (no sentido de que 'tinham validade') ainda antes da codificação legal, enquanto Gibbons (1994: 3), com um enfoque mais linguístico do tema, afirma que "the concepts which now construct legal systems such as 'guilt' and 'murder' are available to us only through the medium of language. There is then a very important sense in which language constructs the law (...).”

Como se torna evidente, estas duas questões, embora distintas, convergem precisamente no sentido de equacionarem uma visão meramente instrumentalista da linguagem verbal humana. Será a linguagem uma mera ferramenta de tradução de um mundo que nos é completamente alheio?

Sabemos hoje que as línguas têm capacidades referenciais, isto é, permitem aos falantes designar entidades e realidades do mundo extralinguístico. 
Esse processo, a que chamamos referir, implica a escolha de um determinado lexema (por entre um sem-número de possibilidades) para designar essa entidade (um ser, um objeto, uma situação) e, como é óbvio, essa opção nunca é inócua; o processo de referir uma entidade é sempre socialmente situado e implica sempre um certo olhar. É indiscutível a mediação subjetiva que o sujeito falante exerce sobre o mundo: ele não acede, através da linguagem, a um mundo exterior, pré-existente e estável; o uso da linguagem constitui já uma tomada de posição face a esse mundo e cada expressão referencial é reveladora das categorizações a que ele o sujeitou. Torna-se, assim, evidente que o processo de referenciação constrói sempre uma determinada visão e versão do mundo.

Considerando agora a tessitura de vozes, de pontos de vista e o caráter eminentemente interlocutivo que perpassam no texto legislativo, compreendemos que as opções linguístico-discursivas do legislador também estão dependentes de certos pontos de vista, de negociações e ajustamentos de sentido, e resultam de uma determinada visão de mundo. Embora tendo como enquadramento uma outra questão, julgamos que as palavras de Machado (2002: 214) são, a este respeito, bastante pertinentes: “(...) a norma, o texto legal, é já uma resposta a uma questão de direito - ela é já uma objetivação linguística de 'pontos de vista jurídicos' e, portanto, pode afirmar-se com segurança, é ela própria já uma interpretação de algo; de algo que está fora dela e para que ela necessariamente remete, (...).”138

Esta interpretação, que corresponde a um olhar jurídico sobre o mundo, implica uma certa categorização desse mundo: mas que tipo de mundo nos comunicam as normas legais? Mais do que um mundo que é, a norma comunica-nos um mundo que deve-ser. ${ }^{139}$ Mais do que um universo factual, estamos perante um universo normativo, ou seja, mais do que a descrição de um estado de coisas, encontramos a estatuição de um conjunto de normas. ${ }^{140}$ As situações nelas previstas corresponderiam

138 Negrito nosso.

139 É a clássica distinção entre Sein e Sollen (ser e dever-ser) proposta por Kelsen.

140 Para uma conceção relativamente diferente da linguagem da lei, veja-se: Villey, M., Kalinowski, G. e Gardies, J.-L., 1974: 33-61. 
a “(...) uma ordem social justa' - conceção que seria sempre baseada numa certa visão da realidade social. ${ }^{141}$ Ora, é relativamente a esta visão da realidade social que se pode trazer à colação a questão da ideologia e das mundividências que estruturam o texto legislativo.

Harris é bem explícita ao afirmar que grande parte dos conceitos jurídicos fundacionais para o Direito das democracias ocidentais é muitíssimo ideológica. ${ }^{142}$ Conforme denunciam algumas correntes críticas $^{143}$, as linguagens no e do poder - linguagens encráticas, como lhes chama Barthes (1984: 97-99) - são ideológicas na medida em que veiculam determinados pontos de vista, apresentando uma categorização particular do mundo e definindo um certo tipo de relações entre os homens. ${ }^{144}$ As linguagens institucionais não constituem exceção. Cada esfera de utilização da língua em cada campo da atividade humana, como o campo jurídico, por exemplo, revela um conjunto de práticas discursivas relativamente estáveis, através das quais se 'fabrica' uma certa visão de mundo. ${ }^{145}$ Enquanto atividade produtora de determinados significados, isto é, enquanto prática cognitiva, a legislação permite 'ordenar' o mundo, permite dar um sentido ao mundo, à realidade social, um sentido que nunca poderá ser objetivo, na medida em que releva da interpretação de um certo grupo social. E de acordo com Weick (1995), “(...) produzir sentido, construir o sensível, não é uma mera interpretação de sinais, antes apela à invenção inerente a todo o processo criativo. Criar sentido é construir, filtrar, enquadrar, criar facticidade, objetivar o subjetivo (...).”146 Neste sentido, a linguagem constitui, pois, a ferramenta fundamental para que o poder legislativo legitime os 'seus' significados, isto é, valide uma certa ordem social (que lhe é favorável), enfim, reproduza a sua ideologia.

141 Cf. Machado, J. B., 2002: 209.

142 "Ver Harris, S., 1994: 157.

143 A área dos Critical Legal Studies e o domínio da Critical Discourse Analysis, por exemplo.

144 Tomamos o termo 'ideologia' na aceção proposta por Eagleton (2000: 29): um conjunto de crenças, valores e categorizações defendidas (e impostas) pela classe detentora de poder.

145 Podemos aproximar a ideia aqui veiculada do conceito de 'formação discursiva' de Foucault.

146 Ver Weick, K., 1995: 43, (cit. por Fernandes, P. C., 2008: 321). 
Não se trata, porém, apenas de um poder a que poderíamos chamar institucional ou até político (numa aceção excessivamente redutora dos termos); neste poder cabe também um saber, um conhecimento privilegiado de um domínio que é o próprio Direito. O conhecimento especializado do sistema jurídico, decorrente de uma longa formação e experiência, torna os profissionais da área detentores de um capital simbólico que não é comparável ao conhecimento detido pelos leigos. Esta distribuição assimétrica dos recursos simbólicos, como a linguagem, é duplamente penalizadora: em primeiro lugar, porque o cidadão comum dificilmente conseguirá igualar as aptidões e competências linguístico-discursivas de um legislador experimentado, que há muito atua com uma profunda consciência metadiscursiva e metajurídica; em segundo lugar, porque este tipo de poder é mais invisível e, portanto, mais difícil de consciencializar, logo insuscetível de identificar e rebater. A monopolização deste conhecimento especializado, vedado ao homem comum, constitui assim uma outra e subtil forma de dominação.

O Direito é, pois, um discurso de autoridade e, neste sentido, o discurso legislativo (ou pelo menos parte dele) pode ser entendido como uma linguagem hermética que constrói um mundo, unívoco e internamente coerente, preservando os poderes instituídos e, em simultâneo, dele excluindo o cidadão comum.

Em jeito de final, deixamos aqui uma incisiva citação de Goodrich (1987: 206): "In explicitly political terms the various doctrinal representations of the coded unity of jurisprudence and of the univocality of legal language constitute an institutional programme or strategy of furtherance of legal professionalism and its inherent belief in the discrete distinctive and expert character of legal practice as an elite occupation."

\section{Considerações finais}

No caminho trilhado ao longo deste texto, procurámos, por um lado, fazer a análise linguístico-discursiva de alguns documentos legais (texto dos Códigos), arrolando algumas características neles evidenciadas e, 
por outro, contextualizar o processo de comunicação que se dá entre o produtor e o(s) recetor(es) desse texto. Tendo em conta a sua proveniência institucional, a lei comunica com uma vasta audiência e não pode ser entendida apenas como um código ${ }^{147}$ ou como um coerente sistema de regras. Ela é um discurso social e, como tal, está relacionada com esse social de que é tanto causa quanto consequência; ela é uma construção social, e as normas, os códigos, os regulamentos em que ela se consubstancia não podem ser dissociados da realidade social que presidiu à sua origem e que lhes definiu o sentido, ou seja, do contexto em que emergiram como atos de comunicação legislativa. ${ }^{148}$

As instituições - como o poder legislativo - são organizações produtoras, estruturadoras e disseminadoras de informação através de determinadas rotinas institucionais padronizadas ${ }^{149}$, o que significa que são organizações humanas cuja operacionalidade se apoia fortemente numa rede comunicacional ${ }^{150}$. Se entendermos a lei como sendo o discurso de uma organização social, isto é, como o conjunto de atos de comunicação de uma instituição, percebemos que ela pretende comunicar com um público amplo, embora essa comunicação só seja eficaz com uma pequena parcela desse público, como vimos. Ora, se este processo comunicacional fracassa com o interlocutor leigo, então o texto legislativo está a falhar um dos seus objetivos maiores: tornar-se compreensível para o cidadão comum a quem ele afeta em primeira instância.

Por outro lado, a construção e a gestão desta rede de informações, ou seja, de sentidos, gerada pela instituição legisladora, releva de uma ideologia própria, que ganha ainda mais legitimidade na exata medida em que não é contestada por ninguém. A opacificação, a ordem e a estabilização dos sentidos veiculados pelo texto legal decorrem, assim, de uma ausência de diálogo e de debate entre o produtor e o recetor deste discurso, para a qual concorre precisamente o desconhecimento do cidadão

${ }^{147}$ Aqui entendido no sentido de conjunto de determinações legais que se aplicam de forma mecânica e cega.

148 Ver Faria, J. E. 1986: 63.

149 Ver Douglas, Mary 1986: 47.

150 Ver Wiio, O. A. 1995: 95-96. 
comum: trata-se de uma "legalidade que, para o leigo, é incompreensível e, portanto, não se discute nem se questiona.” (Carapinha, 2006: 51)

A impenetrabilidade de muitos textos legislativos não é desejável em democracia; nas sociedades democráticas, o acesso à Justiça tem de passar, necessariamente, pelo acesso à linguagem da Justiça e se a linguagem é o fundamento da vida em sociedade, então não se compreende que ela venha a constituir um obstáculo no acesso do homem comum a essa mesma Justiça. 


\section{B I B L I O G R A F I A}

AFONSO, O. (2005). "Dever de reserva - O seu papel na jurisdição". In: AA VV, Balanço da reforma da acção executiva. Segredo de justiça e dever de reserva (Conselho Superior da Magistratura, II Encontro Anual - 2004). Coimbra: Coimbra Editora, pp. 147-154.

ALBINO, C. (2003). «Sim, a Ordem dos Jornalistas». In: Diário de Notícias, 2 de novembro.

AMSELEK, P. (1964). Méthode phénoménologique et théorie du droit. Paris: L.G.D. J.

ANTUNES, F. (1994). "Alta Autoridade está queimada». In: Jornal de Notícias, 14 de março.

AZNAR, H. (2005). Comunicação Responsável - A auto-regulação dos media. Porto: Porto Editora.

BARREIROS, J. A. (2005). "O dever de reserva nas profissões jurídicas». In: AA VV, Balanço da reforma da acção executiva. Segredo de justiça e dever de reserva (Conselho Superior da Magistratura, II Encontro Anual - 2004). Coimbra: Coimbra Editora, pp. 163-170.

BARTHES, R. (1984). O rumor da língua. Lisboa: Ed. 70, (trad. portuguesa).

BECKETT, K. e WESTERN, B. (2001). "Governing social marginality: welfare, incarceration and the transformation of state policy". In: Punishment and Society, 1, pp. 43-59.

BENHABIB, S. (2009). "Rumo a um modelo deliberativo de legitimidade democrática». In: MARQUeS, A. (ed.), A Deliberação Pública e suas Dimensões Sociais, Políticas e Comunicativas. Belo Horizonte: Autêntica Editora.

BERGEL, J-L. (1997). "Du concept de déontologie à sa consécration juridique». In: BERGEL, J-L, (org.), Droit et Déontologies Professionnelles. Aix-en-Provence: Librairie de l'Université.

BHATIA, V. K. (1993). Analysing Genre: Language Use in the Professional Setting. London: Longman.

BHATIA, V. K. (1994). Cognitive structuring in legislative provisions. In: GIBBONS, J. (ed.). Language and the Law. London: Longman.

BHATIA, V. K. (2010). Legal writing: specificity. Specification in legislative writing: accessibility, transparency, power and control. In: Coulthard, M. e Johnson, A. (eds.) 2010. The Routledge Handbook of Forensic Linguistics. London: Routledge.

BIRESSI, A. e NUNN, H. (2003). "Video justice: crimes of violence in social/media space». In: Space \& Culture, 6 (3): pp. 276-291.

BOBBIO, N. (1982). A teoria das formas de governo. Brasília: UnB.

BOBBIO, N. (2000). O futuro da democracia. São Paulo: Paz e Terra.

BOHMAN, J. (2000). "The division of Labor in Democratic Discourse: Media, Experts, and Deliberative democracy». In: Chambers, S. and Costain, A. N. (org). Deliberation, Democracy and the Media. Maryland: Rowman \& Littlefield Publishers. 
BOTTOMS, A. E. (1995). «The philosophy and politics of punishment and sentencing». In: Clakson, C. and Morgan, R. (eds.). The Politics of Sentencing Reform. Oxford: Clarendon Press.

BRES, J. (2005). "Savoir de quoi on parle: dialogue, dialogal, dialogique; dialogisme, polyphonie...» In: Bres, J.; Haillet, P.P.; Mellet, S.; Nølke, H. e Rosier, L. (dirs.). Dialogisme et polyphonie. Approches linguistiques. Bruxelles: De Boeck.

BRKIC, J. e ANDERSON, N. (1988). Drafting and Interpreting Legal Documents. In: Kevelson, R. (ed.). Law and Semiotics. Vol. 2. New York: Plenum Press.

CALHOUN, C. (1996). "Introduction: Habermas and the public sphere». In: Calhoun, C. (ed.) Habermas and the Public Sphere. 4. ${ }^{\mathrm{a}}$ ed., Cambridge: MIT Press, pp. 1- 48.

CAMPS, V. (2004). «Instituiciones, agencias y mecanismos de supervisión mediática». In: CONILL SANCHO, J.; GONZÁLEZ, V. (coords.). Ética de los Medios - Una apuesta por la ciudadanía audiovisual. Barcelona: Editorial Gedisa.

CANIVET, G. e JOLY-HURARD, J. (2004). La déontologie des magistrats. Paris: Dalloz.

CANotilho, G. e MOReira, V. (2007). Constituição da República Portuguesa Anotada, vol. I. Coimbra: Coimbra Editora.

CARAPINHA, M. C. (2006). Contributos para a análise da linguagem jurídica e da interacção verbal em sala de audiências. Dissertação de Doutoramento (não publ.). Coimbra: Faculdade de Letras.

CARMO, R. do (2005). "O dever de reserva - O dever de informar: algumas achas para o debate». In: AA VV, Balanço da reforma da acção executiva. Segredo de justiça e dever de reserva (Conselho Superior da Magistratura, II Encontro Anual -2004). Coimbra: Coimbra Editora, pp. 155-162.

CARPINI, M. D. e WILliAMS, B. A. (2001). «Let Us Infotain You: Politics in the New Media Environment». In: Bennet, W. L.; Entman, R. M. (eds). Mediated politics: communication in the future of democracy. Cambridge: Cambridge University Press, pp. 160-181.

CASTELLS, M. (1999). O poder da identidade (A era da informação: economia, sociedade e cultura; v.2). São Paulo: Paz e Terra.

CHERMAK, S. M. (1995). Victims in the News. Crime and the American News Media. Boulder, San Francisco, Oxford: Westview.

CHIBNALL, S. (1977). Law-and-Order News: An Analysis of Crime Reporting in the British Press. London: Tavistock Publications.

CHRISTIE, G. C. (1964). "Vagueness and Legal Language». In: Minnesota Law Review, 48.

COHEN, J. (1997). Deliberative Democracy. Cambridge: MIT Press.

COHEN, J. (2009). "Deliberação e legitimidade democrática». In: Marques, A. (ed.). A Deliberação Pública e suas Dimensões Sociais, Políticas e Comunicativas. Belo Horizonte: Autêntica Editora.

COHEN, S. (2002). Folk Devils and Moral Panics. The Creation of the Mods and Rockers, 3. ${ }^{\mathrm{a}}$ ed. London, New York: Routledge.

COHEN, S. e YOUNG, J. (1973). The Manufature of News: Deviance, Social Problems and the Mass Media. London: Constable.

CONSELHO REGULADOR (2006). Parecer Relativo ao Anteprojecto da Proposta de Lei que Altera o Estatuto dos Jornalista - Parecer 2/2006.

CORNU, G. (2000). Linguistique Juridique. $2^{\text {a }}$. Ed. Paris: Montchrestien.

CORNU, D. (1994). Journalisme et Vérité. Genebra: Labor et Fides.

CORREIA, J. C. (2005). Sociedade e Comunicação: Estudos sobre Jornalismo e Identidades. Covilhã: UBI. 
COULTHARD, M. e JOHNSON, A. (2007). An Introduction to Forensic Linguistics. Language in Evidence. London: Routledge.

COUlthARD, M. e JOHNSON, A. (eds.) (2010). The Routledge Handbook of Forensic Linguistics. London: Routledge.

CURTIS, P. (2001). Jack the Ripper and the London press. New Haven: Yale University Press.

DOUGLAS, M. (1986). How Institutions Think. New York: Syracuse University Press.

DRYZEK, J. (2004). "Legitimacy and economy in deliberative democracy» In: Farrely, C. Contemporary Political Theory: a Reader. London: Sage.

DRYZEK, J. (2000). Deliberative Democracy and Beyond: Liberals, Critics, Contestations. Oxford: Oxford University Press.

DUBOUCHET, P. (1990). Sémiotique Juridique. Paris: PUF.

DUCROT, O. (1982). La notion de sujet parlant. In: Cahier du Groupe de Recherches sur la Philosophie et le langage, 2. Grenoble: Université de Grenoble.

DUCROT, O. (1984). Le Dire et le dit. Paris: Minuit.

DURKHeIM, É. (1977). A Divisão do Trabalho Social, Vol. 1, trad. de M. I. Freitas. Lisboa: Editorial Presença.

EAGLETON, T. (2000). Ideology: an Introduction. 7. ${ }^{\mathrm{a}}$ ed. London: Verso.

ELSTER, J. (1986). "The Market and the Forum: Three Varieties of Political Theory". In: Elster, J.; Hylland, A. (eds). Foundations of Social Choice Theory, Cambridge: Cambridge University Press, pp. 104-132.

ELSTER, J. (1998). Deliberative Democracy. Cambridge: Cambridge University Press.

ERICSON, R., BARANEK, P. e CHAN, J. (1989). Negotiating Control: A Study of News Sources. Toronto: University of Toronto Press.

ESSER, F. (1999). "Tabloidization of news. A comparative analysis of Anglo-American and German Press Journalism». In: European Journal of Communication, pp. 291-324.

FARIA, J. E. (1986). "A Reforma do Ensino Jurídico». In: Revista Crítica de Ciências Sociais, 21.

FERNANDES, P. C. (2008). "Justiça e media: legitimação pela comunicação». In: Revista do CEJ $\left(n .^{\circ} 10\right)$, pp. 311-346.

FIGUEIREDO, C. e COSTA, R. (1990). "Alta Autoridade da discórdia». In: Expresso - Suplemento A4, 27 de janeiro.

FONSECA, J. (1994). "O lugar da Pragmática na Teoria e na Análise Linguísticas». In: Pragmática Linguística. Introdução, Teoria e Descrição do Português. Porto: Colecção Linguística/Porto Editora, n. ${ }^{\circ} 5$.

FOUCAUlT, M. (1991). Vigiar e Punir: Nascimento da Prisão. 9. ${ }^{a}$ ed., trad. de L. M. P. Vassallo. Petrópolis: Vozes.

FOX, R. L. e SICKEL, R. V. (2001). Tabloid Justice: Criminal Justice in an Age of Media Frenzy. London: Lynne Rienner Publishers Boulder.

FRANKLIN, B. (1997). Newszak \& News Media. London: Hodder Arnold.

FRASER, N. (1996). "Rethinking the public sphere: a contribution to the critique of actually existing democracy» In: Calhoun, C (ed.) Habermas and the Public Sphere. 4. ${ }^{a}$ ed., Cambridge: MIT Press, pp. 109-142.

FRIEDMAN, L. M. (1964-1965). Law and its Language. In: George Washington Law Review, p. 33.

FUENTES GONZÁLEZ, D. (1997). Algunas aportaciones de la sociolingüística al campo del derecho. In: Delgado León, F.; Calero Vaquera, M. L. e Osuna García, F. (eds.), (1998). 
Actas del II Simposio de Historiografía Lingüística. Córdoba: Servicio de Publicaciones de la Universidad de Córdoba.

GALVÃO TELLES, I. (2000). Introdução ao Estudo do Direito. Vol. II. 10 ${ }^{\mathrm{a}}$ ed. Coimbra: Coimbra Editora.

GARAPON, A. (1998). O guardador de promessas. Lisboa: Instituto Piaget.

GARLAND, D. (2001). The Culture of Control. Oxford: Oxford University Press.

GARMENT, S. (1991). Scandal: The Culture of Mistrust in American Politics. New York: Times Books.

GEYH, C. G. (2006). Preserving Public Confidence in the Courts in an Age of Individual Rights and Public Skepticism. http://ssrn.com/abstract=933699: Indiana University School of Law-Bloomington.

GIBBONS, J. (ed.) (1994). Language and the Law. London: Longman.

GIBBONS, J. (2003). Forensic Linguistics. An Introduction to Language in the Justice System. Oxford: Blackwell.

GIBBONS, J. e TURELL, M. T. (eds.) (2008). Dimensions of Forensic Linguistics. Amsterdam: John Benjamins Publishing Company.

GOLDMAN, L. (1994). Accident and absolute liability in anthropology. In: Gibbons (ed.). Language and the Law. London: Longman.

GOODRICH, P. (1987). Legal discourse. Studies in Linguistics, Rhetoric and Legal Analysis. London: Macmillan.

GRABER, D. A. (1980). Crime News and the Public. New York: Praeger.

GREER, C. e JEWKES, Y. (2005). "Extremes of Otherness: Media Images of Social Exclusion». In: Social Justice, 32 (1), pp. 20-31.

GREIMAS, A. J. (1976). Analyse sémiotique d'un discours juridique. In Greimas, A. J.. Sémiotique et sciences sociales. Paris: Seuil.

GRICE, P. (1975). Logic and Conversation. In: Cole, P.; Morgan, J. L. (eds.). Syntax and Semantics 3: Speech Acts. New York: Academic Press.

GUTMANN, A. e THOMPSON, D. (2007), "O que significa democracia deliberativa", In: Revista Brasileira de Estudos Constitucionais, Belo Horizonte, Ed. Fórum, 2007, pp. 17-78.

HABERMAS, J. (1996). Between Facts and Norms. Contributions to a Discourse Theory of Law and Democracy, Cambridge, MA: MIT Press.

HABERMAS, J. (1996), "Three Normative Models of Democracy» In: Benhabib, S. (ed.) Democracy and Difference. Princeton, NJ: Princeton University Press.

HABERMAS, J. (1997). Direito e Democracia - Entre facticidade e validade, vol. II. Rio de Janeiro.

HABERMAS, J. (1998). The Structural Transformation of the Public Sphere: An Inquiry into a Category of Bourgeois Society, 9. ${ }^{\mathrm{a}}$ reimp., trad. de T. Burger. Cambridge, MA: MIT Press.

HABERMAS, J. (2002). "Prefacio a la Nueva Edición Alemana de 1990". In: Historia y Crítica de la Opinión Pública: La Transformación Estructural de la Vida Pública, trad. de F. Gil Martín, $7^{\text {a }}$. reimp., Barcelona: Gustavo Gilli.

HALl, S., CRITCHER, C., JEFFERSON, T., CLARKE, J. e ROBERTS, B. (1978). Policing the Crisis: Mugging, the State, and Law and Order, London: The MacMillan Press.

HARRIS, S. (1994). Ideological exchanges in British magistrates courts. In: Gibbons, J. (ed.). Language and the Law. London: Longman.

HJARVARD, S. (2008). "The Mediatization of Society: a Theory of the Media as Agents of Social and Cultural Change». In: Nordicom Review 29, 2, pp. 105-134. 
HOEY, M (1985). "The Statute as Discourse and the Lawyer as Linguist». In: Hall, R. A. J. (ed.) The Eleventh LACUS Forum 1984. Columbia: Hornbeam Press.

HONNETH, A. (1995). The Fragmented World of the Social: Essays in Social and Political Philosophy. New York: SUNY Press.

HUTCHINGS, P. (1999). «Spectacularizing crime: ghostwriting the law». In: Law and Critique, 10: pp. 27-48.

JACKSON, B. S. (1995). Making Sense in Law. Linguistic, Psychological and Semiotic Perspectives. Liverpool: Deborah Charles Publications.

JALALI, C. (2005). "Nova governação nova cidadania? Os cidadãos e a política em Portugal». In: Revista de Estudos Politécnicos, vol. II, n. ${ }^{\circ} 4$.

JIMÉNEZ, F. J. (1994). «Posibilidades y limites del escandalo politico como una forma de control social». In: REIS Revista Española de Investigaciones Sociológicas, pp. 7-36.

KELSEN, H. (1934). "The pure theory of law, its methods and fundamental concepts". In: Law Quarterly Review, n. ${ }^{\circ} 50$.

KISSELER, L., e HEIDEMANN, F. (2006). «Governança pública: novo modelo regulatório para as relações entre Estado, mercado e sociedade?». In: Revista da Administração Pública, 40 (3), Rio de Janeiro, Maio/Junho.

LAMBERT, P. (2004). "Le devoir de réserve et les notions voisines». In: AA VV. Actes de la Table Ronde organisée par l' Institut d'Études sur la Justice, le 17 octobre 2003, Bruxelles: Bruylant, pp. 9-19.

LEVI, J. N. e WALKer, A. G. (eds.) (1990). Language in the Judicial Process. New York: Plenum Press.

MACHADO, H. e SANTOS, F. (2009). A moral da justiça e a moral dos media: Julgamentos mediáticos e dramas públicos (Oficina do CES $n .^{\circ} 333$ ). Coimbra: CES.

MACHADO, H. e SANTOS, F. (2008). Crime, drama e entretenimento. O caso Maddie e a meta-justiça popular na imprensa portuguesa (Oficina do CES n. ${ }^{\circ}$ 308). Coimbra: CES.

Machado, J. (2002). Liberdade de Expressão. Dimensões constitucionais da esfera pública no sistema social. Coimbra: Coimbra Editora.

MACHADO, J. B. (2002). Introdução ao Direito e ao Discurso Legitimador. (13 $3^{\mathrm{a}}$ reimp.) Coimbra: Almedina.

MALEY, Y. (1994). The Language of the Law. In: Gibbons, J. (ed.). Language and the Law. London: Longman.

MANIN, B. (1987). "On Legitimacy and Political Deliberation». In: Political Theory, 15, pp 338-368.

MANSBRIDGE, J. (1999). "Everyday talk in deliberative system» In: Macedo, S. (ed.). Deliberative Politics: Essays on Democracy and Disagreement. New York: Oxford University Press.

MARMOR, A. (2008). "What Does the Law Say?»In: Analisi e diritto 2007. Ricerche di giurisprudenza analitica. Torino: G. Giappichelli Editore.

MASCARENHAS, Ó. (1998) "Por uma carta 98 da auto-regulação». In: AAVV. $3 .^{\circ}$ Congresso dos Jornalistas Portugueses - Conclusões, teses, documentos, Lisboa, Comissão Executiva do III Congresso dos Jornalistas Portugueses.

MASON, P. (2006) «Lies, distortion and what doesn't work: monitoring prison stories in the British media». In: Crime Media Culture, 2 (3), pp. 251-267.

MATHIESEN, T. (1995). "The eagle and the sun: on panoptical systems and mass media in modern society». In: Ericson, R. (ed.) Crime and the Media. Aldershot, Brookfield USA, Singapore, Sydney: Dartmouth, pp. 333-350. 
MATHIESEN, T. (2004). Essays on the creation of Acquiescense in Modern Society, Winchester: Waterside Press.

MATHIESEN, T. (2006). Prison on Trial, $3^{\mathrm{a}}$. ed., Winchester: Waterside Press.

MATOS, F. A. (2011). Responsabilidade Civil por Ofensa ao Crédito ou ao Bom Nome. Coimbra: Almedina.

MESQUITA, J. (1998). "Aprofundar a autonomia", In: AAVV. 3. ${ }^{\circ}$ Congresso dos Jornalistas Portugueses - Conclusões, teses, documentos. Lisboa: Comissão do III Congresso dos Jornalistas Portugueses.

MOREIRA, V. (1997). Auto-Regulação Profissional e Administração Pública. Coimbra: Almedina, 1997.

NEWBURN, T. e JONES, T. (2007). "Symbolizing crime control». In: Theoretical Criminology, 11(2), pp. 21-243.

OLSSON, J.(2004). Forensic Linguistics. An Introduction to Language, Crime and the Law. London: Continuum.

PAIXÃO, B. (2010). O escândalo político em Portugal (1991-1993 e 2002-2004). Coimbra: Minerva.

PATON, W. R. (1922). Polybius: The Histories, Volume III, Books 5-8 (Loeb Classical Library). London: Heinemann.

PRATT, J. (2007). Penal Populism, London, New York: Routledge.

PUTMAN, E. (1997). "Éthique des affaires et déontologie des professions d'affaires: réflexions sur la morale des marchands». In: BERGEL, J-L. (org.). Droit et Déontologies Professionnelles. Aix-en-Provence: Librairie de l'Université.

RAWLS, J. (1971). A Theory of Justice. Harvard: Harvard University Press.

RAWLS, J. (2001). O Direito dos Povos. São Paulo: Martins Fontes.

RIVERA BEIRAS, I. (2003). "State form, labor market and penal system: the new punitive rationality in context». In: Punishment Society, 7(2), pp. 167-182.

SANDERS, L. (1997). "Against deliberation». In: Political Theory, 25, pp. 347-376.

SANTOS, B. S. et al. (2009). A Justiça Penal: Uma Reforma em Avaliação. Coimbra: Centro de Estudos Sociais da Faculdade de Economia da Universidade de Coimbra.

SCHLESINGER, P. e TUMBER, H. (1994). Reporting Crime: The Media Politics of Criminal Justice. Oxford: Clarendon Press.

SCHLESINGER, P., TUMBER, H. e Murdock, G. (1995). "The media politics of crime and criminal justice». In: ERICSON, R. (coord.) Crime and the Media. Aldershot, Brokfield USA, Singapore, Sydney: Dartmouth, pp 397-420.

SCHUDSON, M. (1978). Discovering the news: a social history of American newspapers. New York: Basic Books.

SCHULZ, W. (2004). "Reconstructing Mediatization as an Analytical Concept». In: European Jounal of Communication Vol 19 (1), pp. 87-101.

SCHUMPETER, J. A. (1994). Capitalism, Socialism, and Democracy. London: Routledge.

SERRANO, E. (2007). "Pensar a regulação dos media numa sociedade em mudança». In: Comunicação e Sociedade ("Regulação dos media em Portugal»), vol. 11, Braga.

SHAPIRO, I. (1999). "Enough of deliberation: politics is about interest and power". In: Macedo, S. (ed.), Deliberative Politics: Essays on Democracy and Disagreement. New York: Oxford University Press.

SHETREET, S. e DESCHÊNES, J. (eds) (1985). Judicial Independence; the contemporary debate. Amsterdam: Martinus Nijhoff. 
SILVA, A. S., (2007). "A hetero-regulação dos meios de comunicação social». In: Comunicação e Sociedade, vol. 11, Braga.

SILVA, V. J. (2006). "Ordem e desordem jornalística». In: Diário de Notícias, 29 de Março.

SILVEIRINHA, M. J. (2004). Identidades, Media e Política: O Espaço Comunicacional nas Democracias Liberais, Lisboa: Livros Horizonte.

SILVEIRINHA, M. J. (2005). "Democracia deliberativa e reconhecimento: repensar o espaço político». In: Correia, J. C. Comunicação e Política. Covilhã: UBI.

SOURIOUX, J-L e LERAT, P. (1975). Le langage du droit. Paris: PUF.

STOFFEL-MUNCK, P., (1997). "Déontologie et moral». In: Bergel, J-L. (org.), Droit et Déontologies Professionnelles. Aix-en-Provence: Librairie de l'Université.

STYGALL, G. (2010). "Legal writing: complexity. Complex documents/average and not-so-average readers". In: Coulthard, M.; Johnson, A. (eds.) (2010). The Routledge Handbook of Forensic Linguistics. London: Routledge.

SURETTE, R. (2010). Media, crime, and criminal justice: images, realities and policies. $4 .{ }^{a}$ ed. Belmont: Wadsworth.

THOMAS, J. (1997). Judicial Ethics in Australia. Sydney: Law Book Co.

THOMPSON, J. (2005). "The new visibility". In: Theory, Culture E Society, 22(6),pp. 31-51.

THOMPSON, J. B. (2002). O escândalo político: poder e visibilidade na era da mídia. Petrópolis: Editora Vozes.

THORNTON, G. C. (1996). Legislative Drafting. London: Butterworth.

THUSSU, D. K. (2007). News as entertainment: the rise of global infotainment. London: Sage.

TIERSMA, P. M. (1993). «Linguistic Issues in the law». In: Language, 69, pp. 113-137.

TIERSMA, P. M. (2000). Legal Language. Chicago: The University of Chicago Press.

VALIER, C. (2002). Theories of Crime and Punishment. Harlow, New York: Longman.

VAN DIJK, T. A. (1990). La Noticia como Discurso: Comprensión, Estructura y Producción de la Información, Paidós: Barcelona.

VAN DIJK, T. A. (2005). Discurso, Notícia e Ideologia: Estudos na Análise Crítica do Discurso, trad. de Z. P. Coelho, Porto: Campo das Letras.

VAN OMMESLACHE, P. (1995) “L'autorégulation». In: AAVV, L'Autorégulation. Bruxelas: Bruylant.

VERDUSSEN, M. (2004). "Le devoir de réserve au regard de la jurisprudence de la Cour Européenne des Droits de l'Homme». In: AA VV, Actes de la Table Ronde organisée par l' Institut d' Études sur la Justice, le 17 Octobre 2003. Bruxelles: Bruylant, pp. 21-31.

VILlEY, M. (1974). "Préface». In: Archives de Philosophie du Droit, Tome XIX.

VILLEY, M., KALINOWSKI, G. e GARDIES, J-L. (1974). "Indicatif et impératif juridiques. Dialogue à trois voix". In: Archives de Philosophie du Droit, Tome XIX.

VIRALlY, M. (1966). "Le phénomène juridique». In: Revue de Droit Public.

WACQUANT L. (2001). "How penal common sense comes to Europeans: notes on the transatlantic diffusion of neoliberal doxa». In: European Societies, 1 (3), pp. 319-352.

WEICHER, M. E. e GOLDSCHMIDT, J. (2007). "The Expansion of the First Amendment in Judicial Elections: Another Cause for Reform». In: Loyola University Chicago Law Journal, pp. 833-894.

WEICK, K. E. (1995). Sensemaking in Organizations. London: Sage. 
WIENER, J. (1988). Papers for the millions; the new journalism in Britain, 1850-1914. New York: Greenwood.

WIIO, O. A. (1995). "Organizational communication. Contingent views». In: Goldhaber G.M.; Barnett G. A. (eds.). Handbook of Organizational Communication. Norwood: Ablex.

WILliAMS, G. (1945). Language and the Law (artigo em 5 partes). In: The Law Quarterly Review 61 (4 partes) e 62 (5. ${ }^{\mathrm{a}}$ parte).

WOLTON, D. (1995). "As contradições do espaço público mediatizado". In: Revista de Comunicação e Linguagens, 21-22, pp. 167-188.

YOUNG, I. M. (2000). Inclusion and Democracy. Oxford: Oxford University Press. 